\title{
Callus induction and plant regeneration of the endemic Astragalus nezaketae in Turkey
}

\author{
Semiha Erisen $^{1} \varangle \cdot$ Mustafa Yorgancilar ${ }^{2} \cdot$ Emine Atalay $^{2} \cdot$ Mehmet Babaoglu $^{3} \cdot$ Ahmet Duran $^{1}$ \\ 1 Department of Biology Education, Ahmet Keleşoğlu Education Faculty, Selçuk University, Konya, Turkey \\ 2 Department of Field Crops, Faculty of Agriculture, Selçuk University, Konya, Turkey \\ 3 Department of Field Crops, Faculty of Agriculture, Selçuk University, Konya, Turkey \\ $\triangle$ Corresponding author: semihaerisen@selcuk.edu.tr \\ Received April 12, 2010 / Accepted August 20, 2010 \\ Published online: November 15, 2010 \\ (C) 2010 by Pontificia Universidad Católica de Valparaíso, Chile
}

\begin{abstract}
A callus induction and plant regeneration protocol was developed from leaf and petiole explants of the endemic Astragalus nezaketae. Explants were cultured on Murashige and Skoog medium (MS) supplemented with different plant growth regulators (PGRs) [ $\alpha$-naphthaleneacetic acid (NAA), benzyladenine (BA), 2,4-dichlorophenoxyacetic acid (2,4-D), kinetin (Kin), thidiazuron (TDZ)]. The combinations and concentrations of PGRs were shown significant variations for the frequency of callus formation, appearence of callus and the potential of callus differentiation. NAA $x$ BA have been found highly affective in callusing and plant regeneration. Other PGRs have not resulted in callus differentiation for shoot formation. The highest number of shoots (6/explants) was obtained from leaf explants cultured on MS with $0.5 \mathrm{mg} / \mathrm{l} \mathrm{NAA}$ and $4 \mathrm{mg} / \mathrm{l} \mathrm{BA}$. The regenerated shoots transferred to rooting medium (MS with $0.5 \mathrm{mg} / \mathrm{l}$ indole-3-butyric acid) were successfully rooted (100\%) and showed rapid elongation. Rooted plantlets were acclimatized in pots containing 1:1 mixture of peat and perlite.
\end{abstract}

Keywords: astragalus, callus, organogenesis, plant regeneration

\section{INTRODUCTION}

Astragalus L. is the largest genus of vascular plants, containing up to 3000 species. It is also the largest genus in Turkey, where it is represented by nearly 455 species in 61 sections (Davis et al. 1988; Duran and Aytaç, 2005). Generally, the genus astragalus is adapted to especially semi-arid regions and steppe areas in Irano-Turanian phytogeographic region of Turkey, which is one of the centers of diversity of the genus (Ghahrema-Ninejad and Behçet, 2003) containing 210 endemic taxa with a rate of endemism of about 47\% (Duman and Akan, 2003; Martin et al. 2008).

Astragalus nezaketae is endemic to Keşis Mountain (Erzincan) and Erzurum, East Anatolia. The species is known only from two populations in the type locality and Erzincan, and from an area of approximately $8000 \mathrm{~m}^{2}$ (criterion B2a). The population is in a poor condition and the number of individuals is estimated to approximately 110-120. Therefore it should be regarded as "Critically Endangered" (IUCN, 2001).

In recent years, with the increasing awareness of extinction risks and loss of genetic variability, ex situ and in situ conservation have been more important. Because of habitat degradation makes the development of in situ conservation difficult, ex situ conservation is currently being promoted. Ex situ conservation methods imply collecting selected or representative samples of the genetic diversity of each species and storing them outside the natural environmental conditions in which the species has evolved. The storage of germplasm of endangered plants is carried out by botanic gardens and dedicated germplasm facilities (seedbanks, field gene banks, tissue and cell culture, cryopreservation) (Heywood and Iriondo, 2003). Seed banking, is used for the maintenance of most collections ex situ often to internationally agreed standards. Because seeds are relatively easy to collect and can be 
stored in a small space (Li and Pritchard, 2009). Although propagation from seed is inexpensive and usually effective, germination requirements for native species are often unknown, particularly for endemic species of which material is more difficult to obtain. A. nezaketae is a new species, and has poor seed germination capacity, due to hard-seed coat resulting in slow seedling development.

Plant tissue culture is a potentially useful technique for growing rare or threatened plants. It can sometimes prove difficult to discover the correct conditions for sustainable growth and re-establishment of plants. However, numerous number of plant regeneration studies were reported in Astragalus adsurgens (Luo and Jia, 1998a; Luo and Jia, 1998b), Astragalus sinicus (Cho and Widholm, 2002), Astragalus cicer (Uranbey et al. 2003; Başalma et al. 2008), Astragalus melilotoides (Hou and Jia, 2004), Astragalus polemoniacus (Mirici, 2004), Astragalus chrysochlorus (Turgut-Kara and Ari, 2008), Astragalus racemosus and Astragalus canadensis (Hung and Xie, 2008). This study describes the first successful in vitro regeneration system of $A$. nezaketae, including plant establishment in the green house.

\section{MATERIALS AND METHODS}

\section{Seed germination and explant preparation}

Seeds of $A$. nezaketae which were classified by Dr. Ahmet Duran were collected from a wild population (B7 Erzincan: Üzümlü, Keşiş Daği, $2450 \mathrm{~m}$ ) in Turkey. Surface sterilization of seeds was carried out with $20 \%$ commercial bleach (HES, Turkey) for 10 min followed by three rinses with sterile distilled water. Some seed coats were incised with a sterile scalpel prior to culture to increase germination rates. Control (unincised) and incised seeds were then placed aseptically in Magenta vessels containing half-strength Murashige and Skoog (MS) medium (Murashige and Skoog, 1962) solidified with $0.8 \%(\mathrm{w} / \mathrm{v})$ agar to obtain aseptic seedling as explant sources. Incised seeds germinated after 4-5 days. Leaf and petiole explants were removed from 30 days old in vitro germinated seedlings.

Table 1. Effects of various auxin and cytokinin combinations on callus induction frequencies of leaf and petiole explants of Astragalus nezaketae.

\begin{tabular}{|c|c|c|c|c|c|c|c|c|}
\hline \multicolumn{2}{|c|}{$\begin{array}{c}\text { Growth regulators } \\
(\mathrm{mg} / \mathrm{l})\end{array}$} & \multicolumn{3}{|c|}{$\begin{array}{l}\text { Frequency of callus } \\
\text { induction* }(\%)\end{array}$} & \multicolumn{3}{|c|}{$\begin{array}{l}\text { Callus fresh weight } \\
\text { (g) }\end{array}$} & \multirow[t]{2}{*}{$\begin{array}{c}\text { Appearance of } \\
\text { callus }\end{array}$} \\
\hline Auxin & Cytokinin & Leaf & Petiole & Mean & Leaf & Petiole & Mean & \\
\hline $\begin{array}{l}2 \text { 2,4-D } \\
42,4-D \\
82,4-D\end{array}$ & $\begin{array}{l}0.5 \mathrm{Kin} \\
0.5 \mathrm{Kin} \\
0.5 \mathrm{Kin}\end{array}$ & $\begin{array}{l}100 a \\
100 a \\
100 a\end{array}$ & $\begin{array}{l}100 a \\
100 a \\
100 a\end{array}$ & $\begin{array}{l}100 a \\
100 a \\
100 a\end{array}$ & $\begin{array}{l}1.00 \\
0.97 \\
0.58\end{array}$ & $\begin{array}{l}1.40 \\
0.85 \\
0.79\end{array}$ & $\begin{array}{c}1.20 \mathrm{~cd} \\
0.91 \mathrm{de} \\
0.68 \mathrm{e}\end{array}$ & $\begin{array}{c}\text { Yellow Soft } \\
\text { Smooth Callus }\end{array}$ \\
\hline $\begin{array}{l}0.2 \text { NAA } \\
0.2 \text { NAA } \\
0.2 \text { NAA } \\
0.5 \text { NAA } \\
0.5 \text { NAA } \\
0.5 \text { NAA }\end{array}$ & $\begin{array}{l}1 \mathrm{BA} \\
2 \mathrm{BA} \\
4 \mathrm{BA} \\
1 \mathrm{BA} \\
2 \mathrm{BA} \\
4 \mathrm{BA}\end{array}$ & $\begin{array}{l}100 a \\
100 a \\
100 a \\
100 a \\
100 a \\
100 a\end{array}$ & $\begin{array}{l}100 a \\
100 a \\
100 a \\
100 a \\
100 a \\
100 a\end{array}$ & $\begin{array}{l}100 a \\
100 a \\
100 a \\
100 a \\
100 a \\
100 a\end{array}$ & $\begin{array}{l}0.97 \\
1.04 \\
1.14 \\
1.53 \\
1.73 \\
1.65\end{array}$ & $\begin{array}{l}1.71 \\
1.67 \\
1.83 \\
1.80 \\
1.77 \\
1.88\end{array}$ & $\begin{array}{c}1.32 \mathrm{bc} \\
1.35 \mathrm{bc} \\
1.49 \mathrm{ac} \\
1.67 \mathrm{ab} \\
1.75 \mathrm{a} \\
1.76 \mathrm{a}\end{array}$ & $\begin{array}{l}\text { Yellowish- } \\
\text { Green Compact } \\
\text { Friable Callus }\end{array}$ \\
\hline $\begin{array}{l}0.0 \text { NAA } \\
0.0 \text { NAA } \\
\text { 0.0 NAA } \\
0.2 \text { NAA } \\
\text { 0.2 NAA } \\
0.2 \text { NAA }\end{array}$ & $\begin{array}{l}\text { 0.2 TDZ } \\
\text { 0.4 TDZ } \\
\text { 0.6 TDZ } \\
\text { 0.2 TDZ } \\
\text { 0.4 TDZ } \\
\text { 0.6 TDZ }\end{array}$ & $\begin{array}{l}20 d \\
40 c d \\
53 b c \\
100 a \\
100 a \\
100 a\end{array}$ & $\begin{array}{c}86 a \\
26 c d \\
73 a b \\
100 a \\
100 a \\
10 a\end{array}$ & $\begin{array}{c}53 b c \\
33 c \\
63 b \\
100 a \\
100 a \\
100 a\end{array}$ & $\begin{array}{l}0.03 \\
0.08 \\
0.13 \\
0.60 \\
0.66 \\
0.62\end{array}$ & $\begin{array}{l}0.10 \\
0.05 \\
0.16 \\
0.88 \\
0.76 \\
0.65\end{array}$ & $\begin{array}{l}0.07 f \\
0.06 f \\
0.15 f \\
0.74 \mathrm{e} \\
0.71 \mathrm{e} \\
0.64 \mathrm{e}\end{array}$ & $\begin{array}{c}\text { Yellow Friable } \\
\text { Granular } \\
\text { Callus }\end{array}$ \\
\hline \multicolumn{2}{|c|}{ Mean } & 87 & 92 & & $0.85 \mathrm{~b}$ & $1.09 a$ & & \\
\hline
\end{tabular}

${ }^{*}$ Responses of leaf and petiole were evaluated together.

Each treatment contains thirty explants.

Numbers in a column with the same letters were not significantly different. 


\section{Callus induction}

Leaf and petiole explants were placed on MS, supplemented with $3 \%$ (Sigma) sucrose and $0.8 \%$ (Sigma) agar in Petri plates. Various combinations of the following plant growth regulators (PGRs) were used for callus induction. 2,4-dichlorophenoxyacetic acid (2,4-D) (2, 4, $8 \mathrm{mg} / \mathrm{l}) \mathrm{x}$ kinetin (Kin) $(0.5$ $\mathrm{mg} / \mathrm{l})$, $\alpha$-naphthaleneacetic acid (NAA) $(0.5,0.2 \mathrm{mg} / \mathrm{l}) \mathrm{x}$ benzyladenine (BA) $(1,2,4 \mathrm{mg} / \mathrm{l})$, thidiazuron (TDZ) $(0.2,0.4,0.6 \mathrm{mg} / \mathrm{l})$ alone or in combination with NAA $(0.2 \mathrm{mg} / \mathrm{l})$. The frequency of explant producing calli and fresh weights $(\mathrm{g})$ of calli were recorded callusing explants after 6 weeks. The $\mathrm{pH}$ of media was adjusted to 5.8 before autoclaving at $121^{\circ} \mathrm{C}$ for $20 \mathrm{~min}$. All cultures were maintained at $24 \pm$ $2^{\circ} \mathrm{C}$ in growth chamber (SANYO: MLR-351H, Japan) with fluorescent light (5 LS) and 16 hrs light and 8 hrs dark photoperiod.

\section{Shoot formation and plant regeneration}

Callus proliferation only occurred on medium with NAA and BA. Calli cultured on MS medium with 0.2 $\mathrm{mg} / \mathrm{BA}$ or without PGRs for shoot formation. After 4 weeks of culture, the frequency of calli producing shoots and shoot number per callus were recorded.

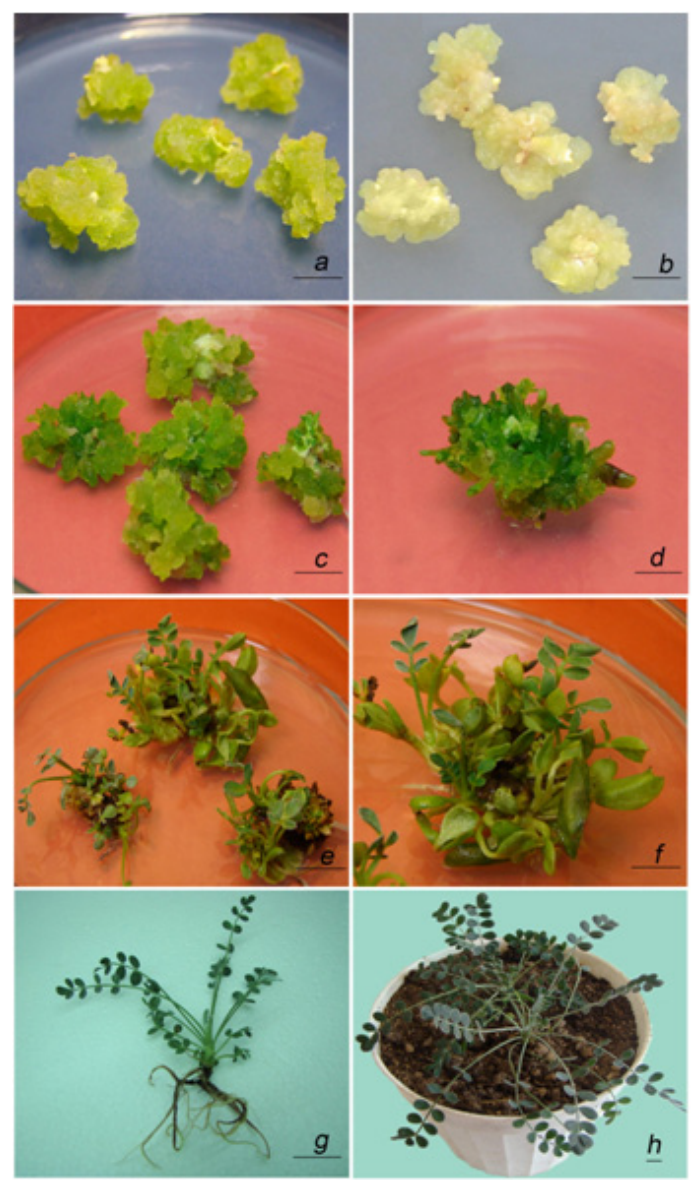

Fig. 1. Callus induction and shoot regeneration from leaf explants of Astragalus nezaketae. Appearance of calli on medium supplemented with: (a) $0.2 \mathrm{mg} / \mathrm{l} \mathrm{NAA}$ and $0.6 \mathrm{mg} / \mathrm{l} \mathrm{TDZ}$. (b) $2 \mathrm{mg} / \mathrm{l} 2.4-\mathrm{D}$ and $0.5 \mathrm{mg} / \mathrm{l} \mathrm{Kin}$. (c) $0.5 \mathrm{mg} / \mathrm{l} \mathrm{NAA}$ and $4 \mathrm{mg} / \mathrm{l} \mathrm{BA}$ after 4 weeks of culture. (d) Development of shoot initials on leaf explants on a medium supplemented with $0.5 \mathrm{mg} / \mathrm{l} \mathrm{NAA}$ and $4 \mathrm{mg} / \mathrm{l} \mathrm{BA}$ after 4 weeks of culture. (e-f) Adventitious shoots on leaf explants on medium supplemented with $0.5 \mathrm{mg} / \mathrm{l} \mathrm{NAA}$ and $4 \mathrm{mg} / \mathrm{l} \mathrm{BA}$ after 8 weeks of culture. (g) Root development on regenerated shoots after 4 weeks on rooting medium. (h) In vitro plantlet after 10 weeks of the transfer to onto plastic pot $(\mathrm{h}),(\mathrm{bar}=1 \mathrm{~cm})$. 


\section{Rooting and acclimatization}

The regenerated shoots $(2-3 \mathrm{~cm})$ from leaf and petiole derived calli, were excised and individually transferred to MS medium with indole-3-butyric acid (IBA) $(0.5 \mathrm{mg} / \mathrm{l})$ contained in $50 \mathrm{ml}$ Magenta vessels for rooting. Rooted plantlets were acclimatized in a growth chamber and transferred to 8 or 16 $\mathrm{cm}$ pots containing 1:1 mixture of peat and perlite and grown till maturity in greenhouse under a day/night temperature regime of $24^{\circ} \mathrm{C}, 16 \mathrm{hrs}$ photoperiod at $90 \%$ humidity.

Five explants were cultured in each culture vessel. Three replicates were used per treatment and each experiment was repeated twice. Significance level was determined by analysis of variance using a two factor completely randomised block design and the differences between the means were compared by LSD test using the Mstat-C statistical program (MStat-C, Version 3, Michigan State University, USA).

\section{RESULTS AND DISCUSSION}

\section{Seed germination}

Unincised seeds showed no germination (0\%) in half-strenght MS medium. However, after seeds were incised with a sterile scalpel germination ratio increased up to $100 \%$ in the same medium. Previous reports tested various applications to achieve adequate germination rates in astragalus species, e.g. sulphuric acid treatment of seeds in $A$. cicer (Başalma et al. 2008), incising seed coats in $A$. polemoniacus (Mirici, 2004) and A. cariensis (Erisen et al. 2010) which produced successful germination yields similar to our study all showed that hard seed coat in astragalus should be incised before culture.

\section{Callus induction}

Callus development from leaf and petiole explants was observed after 1 week of culture on all media tested. Callus induction frequency (\%) in response to different combinations of auxin and cytokinin in MS media is presented in Table 1. Calli were developed in all PGRs combinations; however, callus induction frequency varied significantly $(p<0.01)$ depending on PGRs and their combinations $($ Table 1$)$. The frequency of callus induction was $100 \%$ in all media tested with the exception of the medium including TDZ alone. In these media, the frequencies of callus induction were between $33 \%$ and $63 \%$. The lowest frequency of callus induction (20\%) was obtained from leaf explant on medium including 0.2 $\mathrm{mg} / \mathrm{l} \mathrm{TDZ}$.

Callus fresh weights were determined after 6 weeks of culture. Significant variations $(p<0.01)$ in callus fresh weights were obtained depending on the PGRs (Table 1). NAA x BA combination was more responsive than other PGRs to callus growth. The highest $(p<0.01)$ callus fresh weights were obtained on media including $0.5 \mathrm{mg} / \mathrm{l} \mathrm{NAA} \times 2$ or $4 \mathrm{mg} / \mathrm{l} \mathrm{BA}$. Callus fresh weights decreased on media containing 2,4-D x Kin. The lowest callus fresh weights were obtained on media with TDZ.

The effect of various PGRs on appearence of calli was also investigated (Table 1). Explants cultured on MS medium with 2,4-D x Kin produced yellow, soft and smooth calli (YSSC) (Figure 1b). Calli cultured on medium with TDZ or NAA x TDZ were yellow, friable and granular (YFGC) (Figure 1a). NAA x BA cointaing MS medium produced yellowish green, compact or friable calli (GCFC) (Figure 1c). After 2 weeks some GCFC calli showed differentiation and turned into green, compact, hard and dry callus with shoot primordia on the surface (Figure 1d). However, YSSC and YFGC calli remained undifferentiated.

Similarly, in $A$. polemoniacus, leaf and petiole explants formed organogenic calli on media including NAA and BA (Mirici, 2004). In Tylophora indica, leaf explants cultured on MS including low concentrations of TDZ (<0.55 mg/l) produced nonorganogenic and small calli (Sahai et al. 2010). Hou and Jia (2004) also reported that $2 \mathrm{mg} / \mathrm{l}$ 2,4-D and $1 \mathrm{mg} / \mathrm{l} \mathrm{Kin}$ could induce high frequency of calli from A. melilotoides hypocotyl and stem explants. However, the calli showed no morphogenesis similar to our findings. In $A$. adsurgens, different types of calli occured on media including 2.4-D alone or in combination with BA, and yellow, friable calli which were only obtained in medium with $2 \mathrm{mg} / \mathrm{l} 2,4-\mathrm{D}$ 
and $0.5 \mathrm{mg} / \mathrm{l} \mathrm{BA}$ were observed higher shoot regeneration potantial than the other types of calli (Luo and Jia, 1998b)

\section{Shoot formation and plant regeneration}

After 6 weeks, all calli were transferred on MS medium without plant growth regulators (PGRs) or with BA $(0.2 \mathrm{mg} / \mathrm{l})$ for shoot formation. These media were showed no variation for shoot formation (data not shown). In A. nezaketae, callus induction medium affected the shoot formation. All media including 2 , 4-D $x$ Kin, TDZ and NAA x TDZ tested for callus induction did not yield any morphogenetic calli upon culture on shoot regeneration media. However, media with NAA x BA affected plant regeneration. GCFC calli derived from these media could produce shoots on both of shoot regeneration media. Other researchers (Luo and Jia, 1998b; Luo et al. 1999; Hou and Jia, 2004) also reported similar results as we found that both the type of callus and the medium played an important role in inducing shoot formation in Astragalus ssp.

The number of shoots per explant varied significantly depending on explant type and interaction between explant type and NAA x BA concentrations $(p<0.05)$ (Table 2). Both explants cultured on all the concentrations of NAA x BA media produced healthy shoots. However, calli derived from leaf explants were more responsive than those from petiole explants for shoot regeneration. The highest number of shoots (6) was achieved per leaf explant on medium with $0.5 \mathrm{mg} / \mathrm{l} \mathrm{NAA}$ and $4 \mathrm{mg} / \mathrm{l} \mathrm{BA}$ (Table 2; Figure 1e and Figure 1f), whereas the highest number of shoots regenerated from petiole explants was obtained on medium containing $0.2 \mathrm{mg} / \mathrm{N} \mathrm{NAA}$ and $1 \mathrm{mg} / \mathrm{l} \mathrm{BA}$. These results indicate that the combination and concentrations of PGRs and explant type are highly important in the establishment of a regeneration system as observed in previous reports in astragalus (Luo and Jia, 1998b; Hou and Jia, 2004; Mirici, 2004; Hung and Xie, 2008; Erisen et al. 2010).

\section{Rooting and acclimatization}

The regenerated shoots were transferred to rooting medium (MS with $0.5 \mathrm{mg} / \mathrm{l} \mathrm{IBA}$ ) and were successfully rooted $(100 \%)$ with rapid elongation (Figure $1 \mathrm{~g}$ ). Whole plantlets were transferred to 8 or $16 \mathrm{~cm}$ pots containing 1:1 mixture of peat and perlite and grown till maturity under greenhouse conditions. Plantlets transferred to $8 \mathrm{~cm}$ pots showed more healthy development and higher survival rates $(60 \%)$ (data not shown). Plants grew successfully into normal mature plants (Figure $1 \mathrm{~h}$ ) and set seeds.

In summary, this study presents the first report of plant regeneration via organogenesis from leaf and petiole explants of $A$. nezaketae, a rare endemic species in Turkey. NAA x BA was more effective than other PGR combinations in producing organogenic calli and shoot regeneration. Similarly, NAA x BA has been found highly affected in regeneration of astragalus species via organogenesis (Luo and Jia,

Table 2. The effects of various concentrations of NAA and BA on adventitious shoot regeneration frequencies of leaf and petiole explants of Astragalus nezaketae.

\begin{tabular}{ccccccc}
\hline \multicolumn{2}{c}{$\begin{array}{c}\text { Growth } \\
\text { regulators } \\
\text { (mg/l) }\end{array}$} & \multicolumn{2}{c}{$\begin{array}{c}\text { Frequency of } \\
\text { organogenic } \\
\text { explants (\%) }\end{array}$} & \multicolumn{2}{c}{$\begin{array}{c}\text { Mean number of } \\
\text { shoots/explants* }\end{array}$} \\
\hline BAP & NAA & Leaf & Petiole & Leaf & Petiole \\
1 & 0.2 & 67 & 100 & $3.13 \mathrm{~b}$ & $4.13 \mathrm{ab}$ \\
2 & 0.2 & 93 & 73 & $2.07 \mathrm{c}$ & $3.00 \mathrm{bc}$ \\
4 & 0.2 & 100 & 100 & $3.27 \mathrm{~b}$ & $2.07 \mathrm{bc}$ \\
1 & 0.5 & 67 & 93 & $3.20 \mathrm{~b}$ & $0.90 \mathrm{c}$ \\
2 & 0.5 & 73 & 80 & $3.00 \mathrm{bc}$ & $2.07 \mathrm{bc}$ \\
4 & 0.5 & 87 & 60 & $6.07 \mathrm{a}$ & $3.13 \mathrm{~b}$ \\
\hline
\end{tabular}

*Responses of leaf and petiole were evaluated together.

Each treatment contains thirty calli.Numbers in a column with the same letters were not significantly different. 
1998a; Luo and Jia, 1998b; Hou and Jia, 2004; Mirici, 2004). Shoot regeneration potentials of leaf explants derived calli were superior over calli from petioles. Optimum shoot regeneration medium was MS with $0.5 \mathrm{mg} / \mathrm{l} \mathrm{NAA}$ and $4 \mathrm{mg} / \mathrm{l} \mathrm{BA}$. This regeneration system can be useful for the ex situ conservation and other genetic manipulation studies of $A$. nezaketae.

Financial support: This research was supported by The Scientific and Technological Research Council of Turkey (TUBITAK) Project "Tissue Culture and Cytogenetic Studies in Some Endemic Astragalus L. Species (Leguminosae) for Germplasm Preservation and Agricultural Uses”, Number TOVAG-1060136.

\section{REFERENCES}

BAŞALMA, D.; URANBEY S.; GÜRLEK, D. and ÖZCAN, S. (2008). TDZ-induced plant regeneration in Astragalus cicer L. African Journal of Biotechnology, vol. 7, no. 8. p. 955-959.

$\mathrm{CHO}, \mathrm{H} .-\mathrm{J}$. and WIDHOLM, J.M. (2002). Improved shoot regeneration protocol for hairy roots of the legume Astragalus sinicus. Plant Cell, Tissue and Organ Culture, vol. 69, no. 3, p. 259-269. [CrossRef]

DAVIS, P.H.R.; MILL, R. and TAN, K. (1988). Astragalus L. In: Flora of Turkey and the East Aegean islands. Edinburgh, Edinburgh University Press, vol. 3, p. 114-124.

DUMAN, H. and AKAN, H. (2003). New species of Astragalus(sect. Alopecuroidei: Leguminosae) from Turkey. Botanical Journal of the Linnean Society, vol. 143, no. 2, p. 201-205. [CrossRef]

DURAN, A. and AYTAÇ, Z. (2005). Astragalus nezaketae (Fabaceae), a new species from Turkey. Annales Botanici Fennici, vol. 42, no. 5, p. 381-385.

ERISEN, S.; YORGANCILAR, M.; ATALAY, E. and BABAOGLU, M. (2010). Prolific shoot regeneration of Astragalus cariensis Boiss. Plant Cell, Tissue and Organ Culture, vol. 100, no. 2, p. 229-233. [CrossRef]

GHAHREMANI-NEJAD, F. and BEHÇET, L. (2003). Astragalus subhanensis (Fabaceae), a new species from Turkey. Annales Botanici Fennici, vol. 40, no. 3, p. 209-211.

HEYWOOD, V.H. and IRIONDO, J.M. (2003). Plant conservation: Old problems, new perspectives. Biological Conservation, vol. 113, no. 3, p. 321-335. [CrossRef]

HOU, S.-W. and JIA, J.F. (2004). High frequency plant regeneration from Astragalus melilotoides hypocotyl and stem explants via somatic embryogenesis and organogenesis. Plant Cell, Tissue and Organ Culture, vol. 79, no. 1, p. 95-100. [CrossRef]

HUNG, C.-Y. and XIE, J. (2008). Development of an efficient plant regeneration system for the seleniumhyperaccumulator Astragalus recemosus and the nonaccumulator Astragalus canadensis. HortScience, vol. 43, no. 7 , p. $2138-2142$.

INTERNATIONAL UNION FOR CONSERVATION OF NATURE AND NATURAL RESOURCES (IUCN). (2001). The IUCN red list categories and criteria, version 3.1. Gland, Switzerland, IUCN, 30 p. ISBN 2-8317-0633-5.

LI, D.-Z. and PRITCHARD, H.W. (2009). The science and economics of ex situ plant conservation. Special Issue: Plant science research in botanic gardens. Trends in Plant Science, vol. 14, no. 11, p. 614-621. [CrossRef]

LUO, J.-P. and JIA, J.-F. (1998a). Plant regeneration from callus protoplasts of the forage legume Astragalus adsurgens Pall. Plant Cell Reports, vol. 17, no. 4, p. 313-317. [CrossRef]

LUO, J.-P. and JIA, J.-F. (1998b). Callus induction and plant regeneration from hypocotyl explants of the forage legume Astragalus adsurgens. Plant Cell Reports, vol. 17, no. 6-7, p. 567-570. [CrossRef]

LUO, J.-P.; JIA, J.-F.; GU, Y.-H. and LIU, J. (1999). High frequency somatic embryogenesis and plant regeneration in callus cultures of Astragalus adsurgens Pall. Plant Science, vol. 143, no. 1, p. 93-99. [CrossRef]

MARTIN, E.; DURAN, A.; DINÇ, M.; ERIŞEN, S. and BABAOĞLU, M. (2008). Karyotype analyses of four Astragalus L. (Fabaceae) species from Turkey. Phytologia, vol. 90, no. 2, p. 147-159.

MIRICI, S. (2004). High frequency of adventitious shoot regeneration from leaf and leaf petiol ofendemic Astragalus polemoniacus Bunge. Selçuk University Agricultural Faculty Publications, vol. 18, no. 34, p. 31-34.

MURASHIGE, T. and SKOOG, F. (1962). A revised medium for rapid growth and bio assays with tobacco tissue cultures. Physiologia Plantarum, vol. 15, no. 3, p. 473-497. [CrossRef]

SAHAI, A.; SHAHZAD, A. and ANIS, M. (2010). High frequency plant production via shoot organogenesis and somatic embryogenesis from callus in Tylophora indica, an endangered plant species. Turkish Journal of Botany, vol. 34, no. 1, p. 11-20. [CrossRef]

TURGUT-KARA, N. and ARI, Ş. (2008). In vitro plant regeneration from embryogenic cell suspension culture of Astragalus chrysochlorus (Leguminoseae). African Journal of Biotechnology, vol. 7, no. 9, p. 1250-1255.

URANBEY, S.; COCU, S.; SANCAK, C.; PARMAKSIZ, I.; KHAWAR, K.M.; MIRICI, S. and ÖZCAN, S. (2003). Adventitious shoot regeneration in cicer milkvetch. Biotechnology and Biotechnological Equipment, vol. 17, p. 33-37. 


\section{How to cite this article:}

ERISEN, S.; YORGANCILAR, M.; ATALAY, E.; BABAOGLU, M. and DURAN, A. (2010). Callus induction and plant regeneration of the endemic Astragalus nezaketae in Turkey. Electronic Journal of Biotechnology, vol. 13, no. 6. http://dx.doi.org/10.2225/vol13-issue6-fulltext-3 